\title{
WISP2 wt Allele
}

National Cancer Institute

\section{Source}

National Cancer Institute. WISP2 wt Allele. NCI Thesaurus. Code C52966.

Human WISP2 wild type allele is located within 20q12-q13.1 and is approximately $13 \mathrm{~kb}$ in length. This allele, which encodes WNT 1-inducible-signaling pathway protein 2, may be involved in bone turnover modulation. The wild type allele is expressed aberrantly at decreased levels in colon tumors. 